\title{
Application Design of Catfish Species Specification
}

\author{
Adi Fitri Yanto, Phong Thanh Nguyen, E. Laxmi Lydia, K. Shankar, Satria Abadi, Wahidah \\ Hashim, Andino Maseleno
}

\begin{abstract}
The system is a program inside of the computer and the task is to complete specific need or task. In its development, the system program has been developed for various fields, for example in determining the specification of catfish species. Catfish is a type of fish that live in fresh water. Catfish is easily recognized because their body is slippery, slightly flat elongated, and has long "mustache" that sticks out from around the mouth. Therefore, the researchers wrote this paper to improve service for the society and to facilitate the community in determining the type of catfish.
\end{abstract}

Keywords : catfish, application, specification.

\section{INTRODUCTION}

\section{A. Background}

Beware of buying beef and chicken meat, because there are some rogue traders who sell beef and chicken that are not suitable for consumption just to take advantage. At certain time such as Ramadan and Eid months, many meat traders sell beef and chicken that are not feasible, so consumer must be smart to recognize and distinguish the difference between the quality fresh meat and meat that is not suitable for consumption. If we consumed not feasible meat, it will interfere health. Next, we review some types of beef and chicken deviations and the characteristic of fresh meat that suitable for consumption so we are not wrong in buying.

\section{B.Research Problem}

From the background above, the following research problems are obtained:

1. How to provide easy service for the society?

2. How to make a simple and clear catfish type specification system program?

Revised Manuscript Received on July 22, 2019

* Correspondence Author

Adi Fitri Yanto, Department of Information Systems, STMIK Pringsewu, Lampung, Indonesia.

Phong Thanh Nguyen*, Department of Project Management, Ho Chi Minh City Open University, Vietnam.E-mail: phong.nt@ou.edu.vn

E. Laxmi Lydia, Professor, Vignan's Institute of Information

Technology(A), Department of Computer Science and Engineering, Visakhapatnam, Andhra Pradesh, India. E-mail: elaxmi2002@yahoo.com

K. Shankar, Department of Computer Applications, Alagappa University, Karaikudi, India.

Satria Abadi, Department of Information Systems, STMIK Pringsewu, Lampung, Indonesia.

Wahidah Hashim, Institute of Informatics and Computing Energy, Universiti Tenaga Nasional, Malaysia.

Andino Maseleno, Institute of Informatics and Computing Energy,

Universiti Tenaga Nasional, Malaysia.

\section{Research Objective}

Based on the research problems above, the objectives of this study are:

1. To help facilitate the service for the Society.

2. To make a system program type specification of catfish species.

\section{THEORITICAL FRAMEWORK}

\section{A. The Definition of System}

The system can be defined as a group of integrated elements with the same intend to achieve a goal [1].

The system is a collection of things or activities or sub-system elements that work together or connected in certain way to form a unity to carry out a function to achieve a goal [2].

The system can be defined as an entity or unit consisting of two or more components or subsystems (smaller systems) that are interconnected and related to achieve a goal [2].

From the three system definitions above, it can be concluded that the system is a set of elements that are interconnected with the same intention to achieve a particular goal [3].

\section{B. Delphi}

Delphi 7 is a software or application development program based on object Pascal production from Borland. Delphi is a programming language (development language) that is used to design an application [3]. The advantages of this programming language are productivity, quality, software development, compilation speed, attractive design patterns that are interesting and reinforced with structured programming [4].

\section{DFD}

Data Flow Diagram (DFD) was originally developed by Christ Gane and Trish Sarson in 1979 which are included in the Structured Systems Analysis and Design Methodology (SSADM) written by Chris Gane and Trish Sarson. The system developed is based on the functional decomposition of a system. Tom DeMarco introduced another method in 1980s which changed the square with curved angle (in DFD Chris Gane and Trish Sarson) with circle to denote. This popular DFD is used as a software system analysis model for software systems that will implemented with structured programming. 


\section{Application Design of Catfish Species Specification}

\section{ERD}

The most widely used initial database modeling is the Entity Relationship Diagram (ERD). ERD was developed based on set theory in field of mathematics. ERD is used for relational database modeling. So if the database storage uses OODBMS, database design does not need to use ERD.

\section{ANALYSIS OF PROBLEMS}

The analysis of the problems discussed in this study are as follows:

a. Looking for and gathering facts about the various types of catfish and their specifications [5].

b. Looking for problems in determining the specification of the catfish type [6].

\section{A. Local Catfish}

Fish of Clarias clans are identified by their slippery elongated, non-scaly, with dorsal fin and elongated long anal fin, which are sometimes fused with the caudal fin, making it look like a short eel. The head is hard at the top, with small eyes and a wide mouth located at the end of the muzzle, equipped with four pairs of feelers (barbels) that are very useful for moving in dark water. Catfish also has an additional breathing apparatus in form of a modification of its gill arc. There is a pair of mustaches, which are sharp bone spines in breast fins. Some say that this mustache is not only sharp but also toxic and causes high fever if people are accidentally exposed to the mustache.

\section{B. Dumbo Catfish}

Dumbo catfish was first brought to Indonesia from Taiwan in 1985. This fish is a favorite fish among farmers because of the rapid growth and large body compared to local catfish. For comparison, a 2-month-old Dumbo catfish has double large size compared to a one-year-old local catfish.

According to the exporter, the Dumbo catfish was the result of a marriage between Taiwan catfish namely Clarias Fuscus and Dumbo catfish namely Clarias Mosambicus. But other information says Dumbo catfish is more similar to Clarius Gariepinus, which lives in Kenya, Africa. There are many literature classifies Dumbo catfish into the second type, including this article. Further study is needed in revealing the origin of Dumbo catfish.

From the physical side, Dumbo catfish can be distinguished from local catfish from its blackish green color. Dumbo catfish will also react when shocked or stressed, their skin turns into black or white patches and then will gradually return to their original color. The Dumbo catfish has a mustache like local catfish, but the Dumbo catfish does not release toxin. Dumbo catfish is also suitable to be kept in ground pond because it does not has the habit of making hole. In general, Dumbo catfish can grow faster, bigger and more resistant to disease than local catfish. But in term of taste, Dumbo catfish is more mushy. Some people think that local catfish meat tastes better than Dumbo catfish.

\section{Phyton Catfish}

Unlike the other superior variety that is usually found by researcher, python catfish was found by catfish breeder in Pandeglang District, Banten, in 2004. Python catfish is the result of parent crossing of ex-Thailand F2 catfish brood with local catfish brood. Unfortunately, it is not known and identified yet what species and from what generation the local catfish brood originate. According to the inventor, brood was obtained from local catfish, which was cultivated by local people for generations. But based on some literature, phyton catfish comes from the female parent of F2 ex Thai catfish with the male parent F6 Dumbo catfish.

Python catfish have resistance to cold weather, survival rate (survival rate) of more than $90 \%$. Meanwhile, FCR reached 1 , it means that one kilogram of feed became one kilogram of meat counted from seed stocking to harvest with a maintenance cycle of 50 days. Initially, the Python Catfish project was carried out to answer the complaint of catfish farmers in Banyumundu Village, Pandeglang Regency. They often suffer losses due to the high mortality rate of catfish seed bought in the market, such as Dumbo catfish.

The catfish seeds were apparently not suitable for cultivation in the cold village of Banyumundu, where at night ranging from 17 degrees Celsius. With the try and error method for more than 2 years, they finally found a variety of catfish that suitable with the cold weather which was later called the Python catfish. The quality of the python catfish is also recognized by the Banten Province Aquaculture Fisheries Office.

As the name implies, python catfish has a head shape like a python snake. The movement is more agile than Dumbo catfish and the taste of the meat is more savory and not mushy. In term of taste, Python catfish is more close to local catfish.

\section{Problem Solutions}

By using the Design of Programming System for the specification of catfish species using Borland Delphi will make the conclusion easier and faster to get result [7]. In the Design of Making the Program System specification of catfish type use Borland Delphi with a knowledge base from experts stored in a database [8]. With the right method will make the diagnosis process quickly and has a small error rate. Programming Designing System specification of catfish species using Borland Delphi was also designed with an easy user interface and able to provide information that is easy to understand for even ordinary computer user [9]. One method in the Program Designing System for catfish type specification using Borland Delphi that can be used is the Forward Chaining method [10]. By using this method the author hopes will be able to diagnose catfish species correctly and quickly. So the possibility of diagnosing error is small [11]. 


\section{E. Database Schema}

The database scheme that will be used in Designing Program System for the specification of catfish species [12].

\section{F. Data Dictionary}

Diagnosis data dictionary as in table 1 and Conclusion data dictionary as in table 2 are data dictionary that will be used in Designing of Making Program System of catfish species specification using Borland Delphi.

Table 1 Diagnostic Data Dictionary

\begin{tabular}{|c|c|}
\hline Field Name & Information \\
\hline ID number & $\begin{array}{c}\text { ID diagnostic number } \\
\text { in expert system } \\
\text { website }\end{array}$ \\
\hline Category & Catfish species category \\
\hline Question & Question to Display \\
\hline Yes Answer & True and false \\
\hline Yes & $\begin{array}{c}\text { Final conclusion of } \\
\text { question, if the choice is Yes }\end{array}$ \\
\hline $\begin{array}{c}\text { No } \\
\text { Conclusion }\end{array}$ & $\begin{array}{c}\text { The final conclusion of } \\
\text { the question, if the choice } \\
\text { is not }\end{array}$ \\
\hline
\end{tabular}

Table 2 Data Dictionary Conclusion

\begin{tabular}{|c|c|}
\hline Field Name & Information \\
\hline ID Conclusion & ID Conclusion \\
\hline Conclusion & $\begin{array}{c}\text { The final conclusion is } \\
\text { knowing the type of } \\
\text { catfish. }\end{array}$ \\
\hline
\end{tabular}

\section{G. Database Design}

Database design is used to identify the need of database table needed by Programming Design of The specification system for catfish species by used Borland Delphi is also intended to identify the content and structure of each table that has been generally defined[13] .

Table 3 Diagnosis Table

\begin{tabular}{|c|c|c|c|}
\hline Field Name & Type & Size & Information \\
\hline ID Number & Integer & 3 & Primary \\
& & Key \\
\hline Category & Varchar & 20 & - \\
\hline Question & Text & - & - \\
\hline
\end{tabular}

\begin{tabular}{|c|c|c|c|}
\hline Yes Answer & Integer & 3 & - \\
\hline No Answer & Integer & 3 & - \\
\hline Yes Conclusion & Integer & 3 & - \\
\hline No Conclusion & Integer & 3 & - \\
\hline
\end{tabular}

\section{H. Flowchart}

Flowchart is used to explain how the design of making catfish species specification system runs in determining the specification of catfish species [14].

\section{Diagnosis Table}

The knowledge base in form of meat consumption-worthy symptoms with symptom assessment method required a diagnosis table [15]. Table of diagnoses referred to is as in table 4-5.

Table 4. Specification Type of Local Catfish

\begin{tabular}{|c|c|c|}
\multicolumn{2}{|c|}{ Specification Type of Local Catfish } \\
Characteristic & \multicolumn{2}{|c|}{ Yes/No } \\
\hline Blackish colored & Yes & No \\
\hline Poisonous Mustache & Yes & No \\
\hline Slow Growth & Yes & No \\
\hline
\end{tabular}

Table 5. Specification Type of Dumbo Catfish Specification Type of Dumbo Catfish

\section{$\begin{array}{ll}\text { Characteristic } & \text { Yes/No }\end{array}$}

\begin{tabular}{|c|c|c|}
\hline Bumpy body & Yes & No \\
\hline Greenish Black Colored & Yes & No \\
\hline Non-Toxic Mustache & Yes & No \\
\hline
\end{tabular}

Table 6. Specification Type of Python Catfish

\section{Specification Type of Phyton Catfish}

\section{$\begin{array}{ll}\text { Characteristic } & \text { Yes/No }\end{array}$}

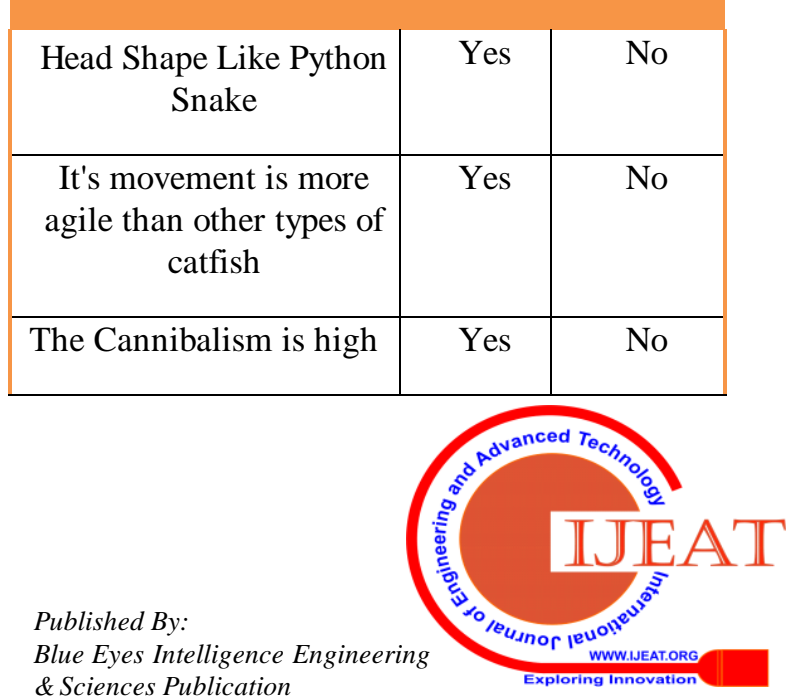




\section{Application Design of Catfish Species Specification}

\section{SYSTEM COMPONENT}

\section{A. System Implementation}

After the system has been analyzed by using certain methods and designed in detail, the system must be implemented [16]. The system implementation stage is the system preparation stage before it is operated.

This stage includes program testing, program installation, and also training for user [17]. After this stage end, it will arrive at the usage stage [18]. In this case, the information started to be operated by user to carry out various activities in determining the specification of catfish species [19].

\section{B .Program Installation}

In this discussion will be explained about the hardware and software configurations needed in the operation of the program [20], operating instruction as well as the result of the operation of the Design Information System of Catfish Species.

\section{Hardware Configuration}

The minimum computer specifications [21] that can be used are as follows:

- Processor Celeron 3.0 GHz Mainboard with VGA onboard Memory 512 Mb DDR2

- Harddisk 40 Gb Case \& PSU Monitor 15" LAN card Keyboard Mouse

\section{Software Configuration}

In order to make this Design of Catfish Type Specification System Program work, there are several software that must be installed. For the server, the software needed are Professional Windows XP Operating System and Borland Delphi 7.

\section{RESULTS AND DISCUSSION}

When designing a system program specification for catfish species find specification or characteristic of catfish species, the main menu will appear first [22]. In this main menu, there is a little explanation about the Design of Making the Catfish type Specification Species System Program and its functions, and there are several buttons that serve as links to the next display.

If the user used the root system then wanted to return to the main menu, they could use the button [23]. Figure 1 shows main menu.

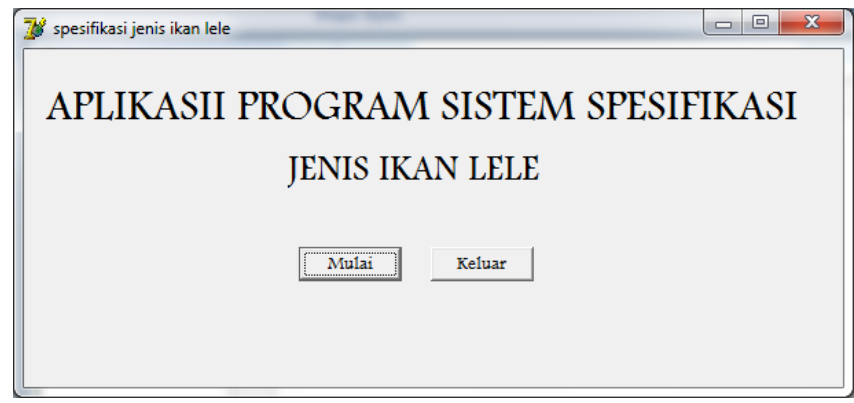

Figure 1. Main Menu

\section{A. Diagnosis Menu}

The How To Diagnose menu as shown in figure 2 can be said to be a guide of the web design of Making Catfish Type Specification System Program using Borland Delphi.

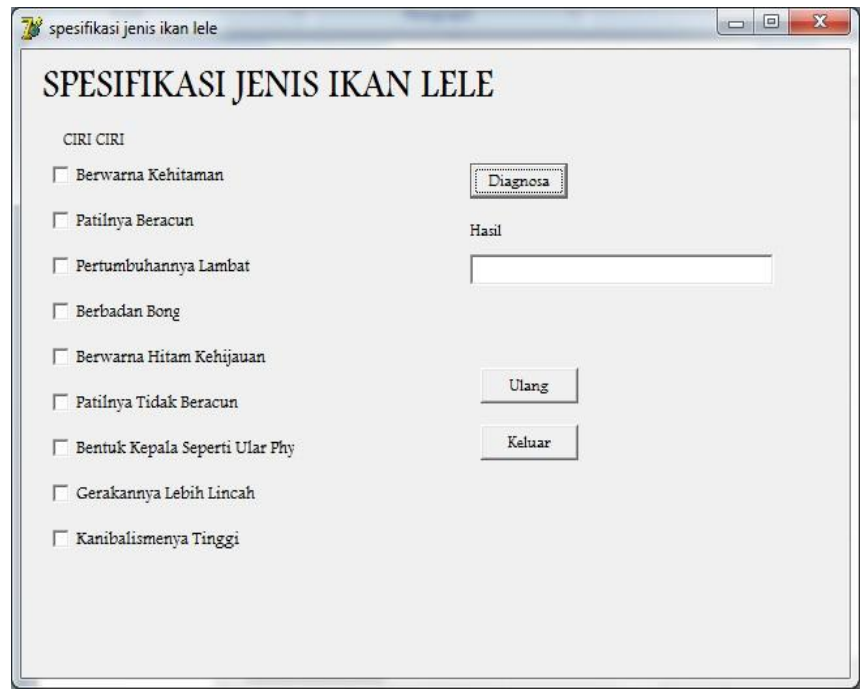

Figure 2. Diagnosis Menu

\section{B. Diagnosis Process}

The diagnostic menu as shown in Figure 3 would appear when the user clicked the "Diagnose" button. The display of the diagnosis menu was quite simple. Showing several check boxes of catfish type specifications.

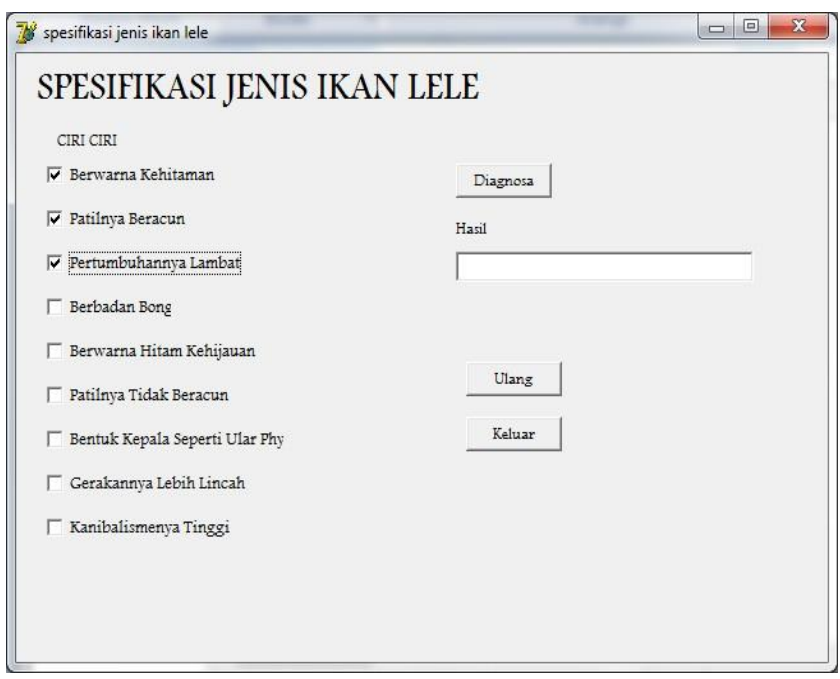

Figure 3. Diagnosis Process

After selecting the symptoms that are experienced, a question or command would appear like the menu in Figure 4. Then under the question there was the Diagnose button menu. If user pressed this button, the conclusion would come out automatically in the next window as shown below. 


\begin{tabular}{|c|c|}
\hline \multicolumn{2}{|l|}{78 spesifikasi jenis ikan lele } \\
\hline \multicolumn{2}{|c|}{ SPESIFIKASI JENIS IKAN LELE } \\
\hline CIRI CIRI & \\
\hline$\sqrt{v}$ Berwarna Kehitaman & Diagnosa \\
\hline$\sqrt{v}$ Patilnya Beracun & Hasil \\
\hline 『 Pertumbuhannya Lambat & Itkan Lele Dumbo \\
\hline \multicolumn{2}{|l|}{$\Gamma$ Berbadan Bong } \\
\hline \multicolumn{2}{|l|}{$\Gamma$ Berwarna Hitam Kehijauan } \\
\hline$\ulcorner$ Patilnya Tidak Beracun & Ulang \\
\hline$\ulcorner$ Bentuk Kepala Seperti Ular Phy & Keluar \\
\hline \multicolumn{2}{|l|}{$\ulcorner$ Gerakannya Lebih Lincah } \\
\hline$\ulcorner$ Kanibalismenya Tinggi & \\
\hline
\end{tabular}

Figure 4.Conclusion

\section{CONCLUSION AND SUGGESTION}

\section{A. Conclusion}

The conclusions that can be drawn from this study are as follows:

1. Design Process of Making Catfish Type Specification System Program by using Borland Delphi matched each specification of catfish species to a conclusion presented in an informative format.

2. Design information Programming System of Catfish Type Specification by using Borland Delphi in a software information can be realized and proses diagnosis dapat berjalan dengan baik.

\section{B. Suggestion}

Seeing the results that have been achieved, it appeared that there were shortcomings, in this case related to the addition of a database of new hardware damage categories. It is expected that the author can design a system that could develop according to the current development conditions.

\section{REFERENCES}

1. Chienwattanasook, K., Wattanapongphasuk, W., Prianto, A., \& Jermsittiparsert, K. 2019. "Corporate Entrepreneurship and Business Performance of Logistic Companies in Indonesia." Industrial Engineering \& Management Systems 18 (3): 538-547.

2. Dawabsheh, M., Hussein, A., \& Jermsittiparsert, K. 2019. "The Triangular Relationship between TQM, Organizational Excellence and Organizational Performance: A Case of Arab American University Palestine." Management Science Letters 9 (6): 921-932.

3. Jermsittiparsert, K., Siam, M., Issa, M., Ahmed, U., \& Pahi, M. 2019. "Do Consumers Expect Companies to Be Socially Responsible? The Impact of Corporate Social Responsibility on Buying Behavior." Uncertain Supply Chain Management 7 (4): 741-752.

4. Syazali, M., Putra, F., Rinaldi, A., Utami, L., Widayanti, Umam, R., \& Jermsittiparsert, K. 2019. "Partial Correlation Analysis Using Multiple Linear Regression: Impact on Business Environment of Digital Marketing Interest in the Era of Industrial Revolution 4.0." Management Science Letters 9 (11): 1875-1886.

5. Maseleno, A., Huda, M., Jasmi, K. A., Basiron, B., Mustari, I., Don, A G., \& bin Ahmad, R. (2019). Hau-Kashyap approach for student's level of expertise. Egyptian Informatics Journal, 20(1), 27-32.

6. Maseleno, A., Huda, M., Siregar, M., Ahmad, R., Hehsan, A., Haron, Z., ... \& Jasmi, K. A. (2017). Combining the previous measure of evidence to educational entrance examination. Journal of Artificial Intelligence, 10(3), 85-90.

7. Sae-Lim, P. \& Jermsittiparsert, K. 2019. "Is the Fourth Industrial Revolution a Panacea? Risks toward the Fourth Industrial Revolution: Evidence in the Thai Economy." International Journal of Innovation, Creativity and Change 5 (2): 732-752.

8. Chatchawanchanchanakij, P., Arpornpisal, C., \& Jermsittiparsert, K 2019. "The Role of Corporate Governance in Creating a Capable Supply Chain: A Case of Indonesian Tin Industry." International Journal of Supply Chain Management 8 (3): 854-864.

9. Hartinah, S., Suharso, P., Umam, R., Syazali, M., Lestari, B., Roslina, R. \& Jermsittiparsert, K. 2020. "Teacher's Performance Management: The Role of Principal's Leadership, Work Environment and Motivation in Tegal City, Indonesia." Management Science Letters 10 (1): 235-246.

10. Maseleno, A., Hardaker, G., Sabani, N., \& Suhaili, N. (2016). Data on multicultural education and diagnostic information profiling: Culture, learning styles and creativity. Data in brief, 9, 1048.

11. Haseeb, M., Hussain, H., Slusarczyk, B., \& Jermsittiparsert, K. 2019. "Industry 4.0: A Solution towards Technology Challenges of Sustainable Business Performance." Social Sciences 8 (5): 184

12. Haseeb, M., Hussain, H., Kot, S., Androniceanu, A., \& Jermsittiparsert, K. 2019. "Role of Social and Technological Challenges in Achieving a Sustainable Competitive Advantage and Sustainable Business Performance." Sustainability 11 (14): 3811.

13. Haseeb, M., Kot, S., Hussain, H., \& Jermsittiparsert, K. 2019. "Impact of Economic Growth, Environmental Pollution, and Energy Consumption on Health Expenditure and R and D Expenditure of ASEAN Countries." Energies 12 (19): 3598.

14. Huda, S., Tsani, I., Syazali, M., Umam, R., \& Jermsittiparsert, K. 2020. "The Management of Educational System Using Three Law Auguste Comte: A Case of Islamic Schools.” Management Science Letters 10 (3) (In press), DOI: 10.5267/j.msl.2019.9.018.

15. Usak, M., Kubiatko, M., Shabbir, M., Dudnik, O., Jermsittiparsert, K., \& Rajabion, L. 2019. "Health Care Service Delivery Based on the Internet of Things: A Systematic and Comprehensive Study." International Journal of Communication Systems 32 (14): e4179.

16. Jermsittiparsert, K., Ambarita, D., Mihardjo, L., \& Ghani, E. 2019 "Risk-Return through Financial Ratios as Determinants of Stock Price: A Study from ASEAN Region.” Journal of Security and Sustainability Issues 9 (1): 199-210.

17. Thabhiranrak, T. \& Jermsittiparsert, K. 2019. "Towards Sustainable Functioning of Organization: Women Empowernment and Corporate Management Culture.” Journal of Security and Sustainability Issues 9 (1): 321-332.

18. Chienwattanasook, K. \& Jermsittiparsert, K. 2019. "Impact of Entrepreneur Education on Entrepreneurial Self-Employment: A Case Study from Thailand." Polish Journal of Management Studies 19 (1): 106-116.

19. Jermsittiparsert, K., Sutduean, J., Sriyakul, T., \& Khumboon, R. 2019 "The Role of Customer Responsiveness in Improving the External Performance of an Agile Supply Chain." Polish Journal of Management Studies 19 (2): 206-217.

20. Jermsittiparsert, K., Sutduean, J., \& Sriyakul, T. 2019. "Effect of Service Innovation and Market Intelligence on Supply Chain Performance in Indonesian Fishing Industry.” Industrial Engineering \& Management Systems 18 (3): 408-417.

21. Jermsittiparsert, K., Namdej, P., \& Somjai, S. 2019. "Green Supply Chain Practices and Sustainable Performance: Moderating Role of Total Quality Management Practices in Electronic Industry of Thailand." International Journal of Supply Chain Management 8 (3) 33-46.

22. Somjai, S. \& Jermsittiparsert, K. 2019. "The Trade-off between Cost and Environmental Performance in the Presence of Sustainable Supply Chain." International Journal of Supply Chain Management 8 (4): 237-247.

23. Jermsittiparsert, K. \& Sawasdee, A. 2012. "Formal Education for Non-Thai or Undocumented Person in Thailand amidst the Challenge of Nationalism and Transnationalism: A Case Study of Wat Sirimongkhol School, Samut Sakhon Province." Kasetsart Journal - Social Sciences 33 (2): 203-213 